\title{
AUDIT COMMITTEE CHAIR CHARACTERISTICS, AND AUDITOR DISMISSAL IN A GOING CONCERN CONTEXT
}

\author{
Dr. Assma M. Sawani \\ Assistant Professor \\ College of Business \\ University of Colorado at Colorado Springs, USA \\ E-mail: asawani@uccs.edu
}

\begin{abstract}
This study examines the role audit committee chair expertise may play in fostering audit quality. The 2002 Sarbanes-Oxley Act (SOX) was enacted to strengthen corporate governance practices in the United States; a fundamental part of this act addressed the audit committee structure and composition. Existing literature suggests that audit committee expertise may improve audit quality. In this study I use a logistic model to compare audit committee chair expertise characteristics for first-time going concern opinion firms that dismissed and did not dismiss the auditor after receiving the going concern opinion for the years 2008-2016 with that of firms that received clean opinions and dismissed or did not dismiss the auditor. I find that audit committee chairs with financial expertise, audit expertise, governance expertise and industry expertise are negatively associated with auditor dismissal. This suggests that firms with these audit committee chair expertise profiles may facilitate better audit quality. Moreover, the chair's audit expertise, industry expertise and financial expertise are differentially significant in the going concern context indicating that these expertise types may temper management's inclination to dismiss auditors after undesirable opinions.
\end{abstract}

Keywords: Audit Committee Chair, Going Concern, Auditor Dismissal, Expertise.

JEL Classification Codes: M41, M42, M49.

\section{INTRODUCTION}

The audit committee fulfills an important responsibility on behalf of company shareholders to oversee the financial reporting process and external audit. After the shocking accounting scandals of the early 2000's, it was not surprising that a main focus of Sarbanes-Oxley Act (SOX) of 2002 was to strengthen corporate governance with particular focus on the audit committee. A key aspect of that focus is determining what combination or different types of directors will best serve the investors. Moreover, in light of the most recent financial crisis, investors and regulators have shown increasing concern with the role of the audit committee and its accountability with respect to the financial statement audit. In 2013 and again in 2019, the Center for Audit Quality (CAQ) sponsored a series of forums to discuss current audit committee practices and goals for strengthening and improving it. A central theme of these roundtable discussions focused on the committee's expertise, and the role of the audit committee chair in enhancing auditor independence and audit quality.

SOX 2002 has a direct impact on the make-up and function of the audit committee as part of an effort to improve the quality of financial reporting and auditing. The Act requires at least one member of the audit committee be designated and disclosed as a financial expert. SOX 2002 also strengthens 
independence requirements for all audit committees by mandating that audit committee members may not be affiliated with the company or any of its subsidiaries and cannot receive direct or indirect compensation from the company beyond that for serving as a board member. It requires public company audit committees to meet specific criteria.

Carcello and Neal (2003) examine the relationship between some of these criteria in the pre-SOX landscape when these criteria were not required and therefore implemented by firms at will. Thus, it is worthwhile to re-examine this issue with a focus on audit committee chair expertise given that the SOX 2002 audit committee requirements have been in effect for a number of years. Such a study can provide insight into whether these requirements continue to play a role in strengthening the committee's monitoring and corporate governance role or if the requirements have become largely symbolic and regulatory check marks. Furthermore, examining audit committee chair expertise and its association with audit and reporting quality can inform regulators and investors as to new avenues for enhancing audit committee effectiveness via focusing on chairs. This study contributes to the wealth of audit committee literature by providing insight into the potential relation between audit committee chair characteristics and audit quality. This is particularly relevant at a time where there is renewed interest in improving the audit process and the audit committee's role in that process. In white paper publications concerning audit committees, both the Center for Audit Quality (CAQ) and the Audit Committee Leadership Network of North America (ACLN), stress the importance of the audit committee chair and reference the chair's expertise in particular as a means of further improvements to the effectiveness of audit committees and oversight of corporate culture (ACLN, 2012; ACLN, 2019; CAQ 2013).

Research that specifically examines the audit committee chair suggests that the busyness of the audit committee chair with other audit committee chair positions leads to a decline in the committees monitoring of the financial reporting process (Tanyi \& Smith, 2015), and that audit committee chair experiential and monitoring expertise is associated with improved financial reporting timeliness (Ghafran \& Yasmin, 2018). Moreover, regulators have expressed an interest in getting greater insight into the unique and dynamic role of the audit committee chair. The Public Company Accounting Oversight Board (PCAOB) surveyed nearly 200 audit committee chairs of public companies in 2019 to gain better insight into their role in the audit committee and improving audit quality (PCAOB, 2020).

Although the audit committee research is expansive, the research focusing on audit committee chairs is less so. I do not find much research examining the audit committee chair's characteristics, specifically other types of expertise, beyond financial in response to auditor dismissals. Using, a sample of firm data for years 2008-2016, I find that firms with audit committee chairs possessing financial expertise, audit expertise, industry expertise, and governance expertise are less likely to dismiss the auditor. Moreover, I find that the audit committee chair's financial and audit expertise, in addition to industry expertise, are associated with a decreased likelihood of auditor dismissal after a going concern opinion. This paper contributes to the literature by providing empirical evidence as to the role AC chair expertise may play in enhancing overall audit committee effectiveness, more specifically in financially weak firms. This is an area of interest to regulators, investors, and the profession. My findings agree with the findings of existing audit committee research and also provides new empirical evidence about the role of audit committee chair characteristics that contributes to the audit committee chair research stream.

This paper is organized in the following manner. The first section after the introduction, section 2, provides the background and predictions of the study. Section 3 provides the details of the logistic model, sample selection and variables, section 4 provides the results, section 5 provides additional analysis and the final section provides the conclusion and limitations of this study. 


\section{Background}

\section{BACKGROUND AND PREDICTIONS}

Many factors can lead to auditor switches or dismissals; these range from changes in management to changes in the client operations that necessitate more or different audit services, and to client disagreement with auditors about fees or procedures (Dye, 1991; Teoh, 1992; Chan, Lin, \& Mo, 2006; Landsman, Nelson, \& Rountree, 2009). A significant portion of this research stream has explored the possibility of auditor dismissal after issuing an undesirable opinion. Specifically, researchers have found that firms facing bankruptcy and/or receiving a going concern opinion are more likely to dismiss the auditor. The implication here is that management may believe it can get the audit opinion it wants from a more agreeable auditor (Schwartz \& Menon, 1985; Archambeault \& DeZoort, 2001; Lee, Mande, \& Ortman, 2004). Combining the auditor switch research with audit committee characteristics in the going concern setting, Carcello and Neal (2000) find that audit committees with greater proportions of affiliated directors are less likely to receive going concern opinions. This study also suggests that auditors believe they are more likely to be dismissed after issuing a going concern opinion when the audit committee is less independent. Evidence suggests that the audit committee's stance in the event of disagreement between management and the auditor is dependent on the committee's knowledge of financial statement adjustments (DeZoort, Hermanson, Archambeault, \& Reed, 2002) and that industry specific expertise on the committee can provide beneficial oversight of the audit process (Cohen, Hoitash, Krishnamoorthy, \& Wright, 2014). Therefore, given these findings, I expect the auditor dismissal after receipt of a going concern report to be an ideal setting in which to examine the possible association between audit committee chair characteristics and the effectiveness of the audit committee in enhancing auditor independence.

The audit committee as a central figure in good governance has a long history; beginning in the 1930s, the SEC and NYSE encouraged the development of such committees. As of June 30, 1978, the NYSE required all listed companies to have audit committees. Yet, the 2002 SOX Act had the most profound impact on the audit committee composition, structure, and responsibilities. In the pre-SOX era, there was minimal regulation that addressed the audit committee's activities and characteristics. Although there were no mandates as to composition of the audit committee pre-SOX, regulators' interest and academic research focused on the audit committee member's financial expertise and its role in committee effectiveness (Public Oversight Board, 1993; SEC, 2003; DeZoort, 1998). The SEC's initial determination of the financial expertise for audit committees caused much debate and controversy (DeFond, Hann, \& Hu, 2005). Ultimately, the SEC went with a much broader definition that largely did not equate financial expertise with accounting financial expertise. Early studies in the post-SOX period provide evidence that most firms' audit committees have non-accounting financial expertise (DeFond, Hann, \& $\mathrm{Hu}, 2005)$.

In its October 2014 publication titled Improving Audit Committee Performance, the ACLN discussed the ever-increasing regulatory disclosure demands and the audit committee structure. Again, much emphasis was placed on the importance and role of other forms of expertise in creating and maintaining an effective audit committee (ACLN, 2014). Furthermore, the significance of other forms of expertise and the dynamic role of the audit chair was at the forefront of discussion at the CAQ's 2013 Conference of the Global Governance Community (CAQ, 2013). Also, in a ten-year review of the impact of SOX, the PCAOB's Investor Advisory Group report noted that although SOX had undoubtedly improved audit quality and corporate governance, further improvements are needed. In particular, the report noted that strengthening the expertise requirements, especially tightening the financial expertise criteria is critical (PCAOB, 2012). 


\section{Audit Committee and Audit Committee Chair Literature}

Existing studies examine the role of audit committee chair characteristics or expertise with respect to timeliness of financial reporting (Abernathy, Beyer, Masli, \& Stefaniak, 2014), financial performance (Chaudhry, Roomi, \& Aftab, 2020), audit report lag (Ghafran \& Yasmin, 2018), resolution of auditor client disagreements (Salleh \& Stewart, 2013), and financial reporting quality (Tanyi \& Smith, 2015; AlAbsy, Ismail, \& Chandren, 2019). To date, little research focuses specifically on the role the audit committee chair may play in audit committee effectiveness (Carcello, Hermanson, \& Ye, 2011). The profession recognizes that the audit committee chair plays a central role in interactions with CEO/CFO and the external auditor (PricewaterhouseCoopers, 2003). The audit committee chair is the individual who is most important in setting meeting agendas and direction (Beasley, Carcello, Hermanson, \& Neal, 2009); the chair is also responsible for the monitoring financial reporting which suggests that the chair's expertise is an important ingredient of audit committee effectiveness (Schmidt \& Wilkins, 2013). Bédard and Gendron (2010) find the audit committee chair responsible for developing appropriate relationships with auditors and management and nurturing a positive working relationship among committee members. Lee and Stone (2003) find that audit committee chair expertise is associated with audit committees with greater expertise and experience whereas Alhababsah and Yekini (2021) find audit committee chair legal expertise has no impact on audit quality. Martinov-Bennie, Soh and Tweedie (2015) provide insight into the changing role of audit committees and chairs beyond just meeting regulatory requirements. The ACLN 2014 Conference focused on the role of the audit committee chair with conference attendees agreeing that the chair's leadership and expertise set the tone for the committee. Furthermore, both investors and audit committee members at the conference noted that at least one member of the audit committee, preferably the chair, should have deeper expertise---expertise that allows the person to make judgments as to the audit work, hours, and procedures.

\section{Predictions}

To extend existing research and provide new insights of interest to regulators and other stakeholders, I examine the expertise characteristics of audit committee chairs. Thus taking into consideration these sentiments from the profession and previous research concerning the audit committee, I expect the audit committee chair's financial expertise as defined by the SEC to decrease the likelihood of auditor dismissal after a going concern report. I make no predictions as to legal expertise since the research findings for this characteristic are mixed. Moreover, I expect audit expertise and industry expertise to decrease the likelihood of auditor dismissal after a going concern opinion. My prediction is that an audit committee chair with deeper financial expertise, as characterized by audit expertise and greater knowledge and understanding of the audit process, will be less inclined to spuriously dismiss the auditor. Also, chairs that have more industry experience will have more knowledge about the risks and rewards of the industry. Whereas AC chairs with governance experience will have greater understanding of their responsibilities and more awareness of the reputation risks of dismissing the auditor after a going concern opinion (Carcello \& Neal, 2003). Therefore, I expect chairs with more governance experience to be less likely to dismiss the auditor after going concern opinion.

\section{Model and Variables}

\section{MODEL, VARIABLES, AND SAMPLE}

I use a modified version of the logistic model used by Carcello and Neal (2003) to examine the relation between auditor dismissal and audit committee chair characteristics:

$$
A U D \_D I S M I S S=\beta_{0}+\beta_{1} * C T E N+\beta_{2} * C T E N^{*} G C+\beta_{3} * C F E X+\beta_{4} * C F E X * G C
$$




$$
\begin{aligned}
& +\beta_{5}{ }^{*} C A U E X+\beta_{6}{ }^{*} C A U E X^{*} G C+\beta_{7} * C L E X+\beta_{8} * C L E X^{*} G C \\
& +\beta_{9} * C I N E X+\beta_{10}{ }^{*} C I N E X^{*} G C+\beta_{11} * C G V E X+\beta_{12} * C G V E X * G C \\
& +\beta_{13}{ }^{*} C C H G+\beta_{14} * C C H G^{*} G C+\beta_{15} * S I Z E+\beta_{16} * I N O W N+\beta_{17} * B O W N \\
& +\beta_{18} * A U T E N+\beta_{19} * A U I N D+\beta_{20} * C E O C H+\beta_{21} * C F O C H+\beta_{22} * M E M \\
& +\beta_{23}{ }^{*} C H G+\beta_{24} * Z F C+e
\end{aligned}
$$

$A U D \_D I S M I S S$ is equal to one if the firm dismissed the auditor before the next annual report, otherwise zero. $G C$ is equal to 1 if the firm received a going concern opinion, otherwise zero. CTEN is the tenure of the audit committee chair as chair. CFEX is equal to 1 if the audit committee chair is designated as a financial expert by the firm in the 10-K or Def-14 filing, otherwise equal to zero. CAUEX is equal to 1 if the audit committee chair has audit expertise, otherwise equal to zero. CLEX is equal to 1 if the audit committee chair has legal expertise, otherwise equal to zero. CINEX is equal to 1 if the audit committee chair has industry expertise, otherwise equal to zero. CGVEX is number of directorships in public companies held by the audit committee chair. $C C H G$ is equal to 1 if the firm experienced a change in audit committee chair before the next annual report, otherwise equal to zero. With respect to the control variables, SIZE is the natural log of total assets. BOWN is the percentage of block ownership (5\% or more) in the firm. INOWN is the percentage of firm shares owned by insiders. AUIND is the percentage of the square root of the total assets that the auditor audits for all the companies in the client's industry. AUTEN is auditor tenure. $C E O C H$ is equal to 1 if the firm experienced a change in CEO before the next annual report, otherwise equal to zero. $C F O C H$ is equal to 1 if the firm experienced a change in $\mathrm{CFO}$ before the next annual report, otherwise equal to zero. $M E M$ the number of audit committee members. $C H G$ is equal to 1 if the firm experienced a change in the audit committee before the next annual report, otherwise equal to zero. ZFC is Zmijewski's (1984) financial condition score to control for financial distress.

The focus of this study is on the possible association between auditor dismissal and audit committee chair characteristics in a going concern scenario. However, following prior research, I include clean opinions as a means of assessing whether the findings for audit committee chairs and auditor dismissals are not exclusive to the going concern scenario. Thus, the coefficients in model associated with main effects of audit committee chair characteristics, capture the relationship between the characteristics and dismissals after a clean opinion.

I use the SEC definition of financial expertise. Extant research suggests a positive association between audit committee members' financial expertise and monitoring of the external auditor (Carcello, Hermanson, Neal, \& Riley, 2002; Carcello \& Neal, 2003; Abbott, Parker, Peters, \& Raghunandan, 2003); and audit quality as measured by no audit fees (Naiker, Sharma \& Sharma, 2013) and by restatements (Cohen et al., 2014). Therefore, I expect audit committee chair's financial expertise $\left(\beta_{3}+\beta_{4}<0\right)$ to be negatively associated with auditor dismissal. It is difficult to objectively define expertise; however a deep and well-founded research stream in cognitive psychology intimates that expertise arises from many hours of deliberate practice or work at a task. Researchers do not have a consensus as to the definition of 'many hours' with some studies proposing five years and others ten years (Haerem \& Rau, 2007; Weiss $\&$ Shanteau, 2014). Given that most CPA's must work at least five years before promotion to audit manager, I define audit expertise as work experience in public company auditing for at least five years. Contessotto and Moroney (2014) find that auditors value audit committee's participation in negotiations and its willingness to use professional judgement to challenge management over the treatment of contentious accounting issues as a measure of an effective audit committee. I expect audit expertise $\left(\beta_{5}+\right.$ $\left.\beta_{6}<0\right)$ to be negatively associated with auditor dismissal. A committee chair is defined as a legal expert if $\mathrm{s}$ /he has a law school degree or has work experience as a lawyer at a law firm or as legal counsel. A committee chair is considered to have industry expertise if the biographical information in the SEC filings 
indicates that the member had at least five years executive/managerial work experience in the firm's industry. Cohen et al. (2014), find that audit committee industry expertise enhances financial reporting quality. Thus, I expect industry expertise to be negatively associated with dismissal. Chairs that serve on other boards may have greater governance expertise, and therefore, I expect a negative relationship between auditor dismissal and the audit committee chair's governance expertise $\left(\beta_{11}+\beta_{12}<0\right)$. I also expect a negative association for audit committee chair tenure $\left(\beta_{1}+\beta_{2}<0\right)$; and a positive association for audit committee chair turnover $\left(\beta_{13}+\beta_{14}>0\right)$.

I select control variables based on existing precedence. Previous literature has extensively documented that larger firms are less likely to dismiss their auditor and tend to have more incentives to maintain the same auditor for a longer-term. Thus, I expect larger firms to be less likely to dismiss the auditor. I also control for $\mathrm{CEO} / \mathrm{CFO}$ turnover as previous research has shown that a change in management often accompanies a change in auditor and poor performance (Menon \& Williams, 2008; Hennes, Leone, \& Miller, 2014). Carcello and Neal (2003) note that new management could change auditors as part of pursuing new goals. I expect a change in the CFO or CEO to be positively associated with auditor dismissal. Furthermore, prior research has established that audit industry specialists and auditors with longer tenures are less likely to be dismissed; thus I include these as control variables. I also control for insider and block ownership (Cohen, Krishnamoorthy, \& Wright, 2002). Finally, I include the Zmijewski Financial Condition Score as a control for poor financial performance since poor performance firms are more likely to dismiss their auditor.

\section{Sample Selection}

For the years 2008 to 2016, the Audit Analytics database has 1,193 publicly traded firms that both received first time going concern opinions (defined as not having received a going concern opinion in the previous five years) and dismissed their auditors. I specifically limit my sample to firms that dismiss their auditor and I do not include any firms in which the auditor resigned or declined reappointment. Because I use Zmijewski's (1984) financial condition index as a control variable, I follow precedence established in previous studies and exclude firms within the financing and services industries (SIC code of 6000 and above). From the initial sample, I eliminate 54 firms that declared bankruptcy, 857 firms that did not have all the requisite financial data in COMPUSTAT, and 152 firms for which I could not find SEC filings with biographical data about the audit committee. The final sample of going concern dismissal firms is 130. I match these firms on industry, year, and size with 130 firms that meet the going concern criteria and did not dismiss the auditor. I match companies first at the four-digit SIC code, then the three-digit SIC code, and finally at the two-digit SIC code where possible. I match 72 firms at the 4-digit SIC, 32 at the 3-digit SIC, 18 at the 2-digit SIC and 8 at the 1-digit SIC. I did not impose a strict match on company size so as to avoid limiting the number of observations included in the study. Table 1 provides the sample selection details.

I also collected data from a sample of clean opinion firms that dismissed the auditor as a basis for comparison. For fiscal years ended 2008-2016, Audit Analytics provides 1,118 firms that received clean audit opinions and did not have a going concern opinion in the previous five years that dismissed the auditor. Of these firms, 426 did not have necessary financial information in COMPUSTAT. From the remaining 692 firms, I used SAS to generate a random sample of 250. Of these 250 firms, 33 did not have $10-\mathrm{K}$ or proxy forms with available audit committee data. I also had to eliminate another 17 firms for which I could not find match firms. Firms that disagree with their auditors are more likely to dismiss the auditor, thus I eliminated the seven firms from my sample for which the Audit Analytics database indicated management/auditor disagreement. This is done to maintain the distinction between going concern sample and the clean sample. Once again, I matched the firms on industry, year, and size. I 
matched 131 firms at the 4-digit SIC, 40 firms at the 3-digit SIC code, 16 firms at the 2-digit SIC code and six firms at the 1-digit SIC code. Table 1 provides the sample selection details.

Table 1. Sample selection criteria

\begin{tabular}{|c|c|}
\hline \multicolumn{2}{|l|}{ Going Concern Opinion Sample ${ }^{a}$} \\
\hline Initial going concern firms that dismissed auditor & 1193 \\
\hline Less firms that declared bankruptcy & $(54)$ \\
\hline less firms with no Compustat Data & -857 \\
\hline less firms with no 10-K/Proxy Statements & $(152)$ \\
\hline Dismissal Sample & 130 \\
\hline No-dismissal Sample ${ }^{b}$ & 130 \\
\hline \multicolumn{2}{|l|}{ Clean Opinion Sample ${ }^{c}$} \\
\hline Initial clean opinion firms that dismissed auditor & 1118 \\
\hline less firms with no Compustat data & $(426)$ \\
\hline Random Selection of 250Firms & 250 \\
\hline Disagreement with management & $(7)$ \\
\hline less firms with no 10-K/Proxy Stmt & $(33)$ \\
\hline less firms with no match & $(17)$ \\
\hline Dismissal Sample & 193 \\
\hline Non-dismissal Sample ${ }^{b}$ & 193 \\
\hline \multicolumn{2}{|c|}{$\begin{array}{l}\text { The going concern sample consists of public companies that dismissed their } \\
\text { auditor after receiving a going concern opinion for the first time, excluding } \\
\text { financial and services companies. A first-time going concern company is one } \\
\text { that did not receive a going concern opinion in the previous five years, for the } \\
\text { years } 2008-2016 . \text { b }^{\text {b }} \text { Every firm in the sample that dismissed the auditor is } \\
\text { matched with a firm that did not dismiss the auditor. The matching is based } \\
\text { on year, industry, and size. }^{c} \text { The clean opinion sample consists of random } \\
\text { sample, generated using SAS, of public companies that dismissed the auditor } \\
\text { after receiving a clean opinion for the years } 2008-2016 \text {. These companies are } \\
\text { matched with companies that received clean opinions and did not dismiss the } \\
\text { auditor. }\end{array}$} \\
\hline
\end{tabular}

\section{Univariate Analysis and Correlations}

\section{RESULTS}

Table 2 provides descriptive statistics divided by auditor dismissal for the control variables and the audit committee chair characteristics for the full sample; for the clean audit opinion sample and the going concern sample, I only provide descriptive statistics for the audit committee chair characteristics. For the full sample with respect to management change control variables, $28 \%$ of firms that dismissed their auditors changed CFO and $21 \%$ changed CEO whereas for the firms that did not dismiss their auditor, $15 \%$ changed CFO ( $p<0.01)$ and $15 \%$ changed CEO ( $p$-value $<0.05$ ). The dismissal group had $46 \%$ block ownership and mean auditor tenure of 8.76 whereas the non-dismissal group had $43 \%$ block ownership and a shorter mean auditor tenure of 6.50 (p-value $<0.01$ ). Between the dismissal and non- 
dismissal groups, there are statistically significant differences for some but not all of the audit committee characteristics. For the dismissal group, $45 \%$ experienced a changed in audit committee members whereas the non-dismissal group had $37 \%$ (p-value < 0.05 ). The non-dismissal group on average has 3.31 audit committee members whereas the dismissal group has mean audit committee members of 3.12 ( $\mathrm{p}$ value $<0.01)$. Examining the audit committee chair characteristics reveals that $20 \%$ of the dismissal group change audit committee chairs whereas $13 \%$ of the non-dismissal group do so (p-value $<0.01$ ). I also find that for the dismissal group the chairs hold fewer directorships in other firms (p-value $<0.01$ ). However, the dismissal group is more likely to have a chair with industry expertise ( $p$-value $<0.01)$. The descriptive data for the clean sample indicates that the dismissal group committee chairs hold fewer directorships in other firms when compared to audit committee members and chairs for the non-dismissal group ( $\mathrm{p}$-value $<0.05$ ). The dismissal group was also more likely to have a committee chair with industry expertise.

Table 2. Descriptive Statistics for Audit Committee Chair Characteristics and Control Variables

\begin{tabular}{|c|c|c|c|c|c|c|c|c|c|c|c|c|}
\hline \multicolumn{13}{|c|}{ Mean [Median] (Standard Deviation) } \\
\hline \multicolumn{5}{|c|}{ Panel A: Full Sample } & \multicolumn{4}{|c|}{ Panel B: Clean Opinion Sample } & \multicolumn{4}{|c|}{ Panel C: Going Concern Sample } \\
\hline \multirow[t]{2}{*}{ Variable } & \multirow{2}{*}{$\begin{array}{l}\text { Non- } \\
\text { Dismissal } \\
(\mathrm{n}=323)\end{array}$} & \multirow{2}{*}{$\begin{array}{l}\text { Dismissal } \\
(\mathrm{n}=323)\end{array}$} & \multirow[t]{2}{*}{ Difference $^{\mathrm{d}}$} & & \multirow{2}{*}{$\begin{array}{l}\text { Non- } \\
\text { Dismissal } \\
(n=193)\end{array}$} & \multirow{2}{*}{$\begin{array}{l}\text { Dismissal } \\
(\mathrm{n}=193)\end{array}$} & \multirow[t]{2}{*}{ Difference $^{\mathrm{d}}$} & & \multirow{2}{*}{$\begin{array}{l}\text { Non- } \\
\text { Dismissal } \\
(\mathrm{n}=130)\end{array}$} & \multirow{2}{*}{$\begin{array}{l}\text { Dismissal } \\
(\mathrm{n}=130)\end{array}$} & \multirow[t]{2}{*}{ Difference } & \\
\hline & & & & & & & & & & & & \\
\hline \multicolumn{13}{|c|}{$\begin{array}{lcc}\text { Audit Committee } & \text { Chair } \\
\text { Characteristics } & \\
\end{array}$} \\
\hline \multicolumn{13}{|c|}{\begin{tabular}{|l|l|l}
$\mathrm{CCHG}$ & & \\
\end{tabular}} \\
\hline & 0.13 & 0.20 & -0.07 & $* *$ & 0.09 & 0.11 & -0.02 & & 0.18 & 0.32 & -0.14 & $* * *$ \\
\hline & {$[0.00]$} & {$[0.00]$} & {$[0.00]$} & $* *$ & {$[0.00]$} & {$[0.00]$} & {$[0.00]$} & & {$[0.00]$} & {$[0.00]$} & {$[0.00]$} & $* *$ \\
\hline & $(0.33)$ & $(0.40)$ & & & -0.29 & -0.32 & & & -0.38 & -0.47 & & \\
\hline \multicolumn{13}{|l|}{ CTEN } \\
\hline & 4.40 & 4.20 & 0.20 & & 4.65 & 4.72 & -0.07 & & 4.04 & 3.42 & 0.62 & $*$ \\
\hline & {$[4.00]$} & {$[3.00]$} & [1.00] & & {$[4.00]$} & {$[4.00]$} & {$[0.00]$} & & {$[3.00]$} & {$[3.00]$} & {$[0.00]$} & $* *$ \\
\hline & $(3.28)$ & $(3.42)$ & & & -3.41 & -3.52 & & & -3.05 & -3.12 & & \\
\hline \multicolumn{13}{|l|}{ CFEX } \\
\hline & 0.88 & 0.84 & 0.04 & & 0.87 & 0.91 & -0.04 & & 0.90 & 0.74 & 0.17 & $* * *$ \\
\hline & {$[1.00]$} & {$[1.00]$} & {$[0.00]$} & & {$[1.00]$} & {$[1.00]$} & {$[0.00]$} & & {$[1.00]$} & {$[1.00]$} & {$[0.00]$} & $* *$ \\
\hline & $(0.32)$ & $(0.37)$ & & & -0.34 & -0.29 & & & -0.30 & -0.44 & & \\
\hline \multicolumn{13}{|l|}{ CAUEX } \\
\hline & 0.25 & 0.21 & 0.04 & & 0.25 & 0.32 & -0.06 & & 0.25 & 0.05 & 0.20 & $* * *$ \\
\hline & {$[0.00]$} & [0.00] & {$[0.00]$} & & [0.00] & {$[0.00]$} & {$[0.00]$} & & {$[0.00]$} & {$[0.00]$} & {$[0.00]$} & $* * *$ \\
\hline & $(0.44)$ & $(0.41)$ & & & -0.44 & -0.47 & & & -0.44 & -0.23 & & \\
\hline \multicolumn{13}{|l|}{ CLEX } \\
\hline & 0.06 & 0.07 & -0.01 & & 0.07 & 0.06 & 0.01 & & 0.05 & 0.08 & -0.04 & \\
\hline & {$[0.00]$} & {$[0.00]$} & {$[0.00]$} & & {$[0.00]$} & {$[0.00]$} & {$[0.00]$} & & {$[0.00]$} & {$[0.00]$} & {$[0.00]$} & \\
\hline & $(0.24)$ & $(0.25)$ & & & -0.25 & -0.23 & & & -0.21 & -0.28 & & \\
\hline \multicolumn{13}{|l|}{ CINEX } \\
\hline & 0.43 & 0.62 & -0.19 & ** & 0.32 & 0.92 & -0.60 & $* * *$ & 0.58 & 0.17 & 0.41 & $* * *$ \\
\hline
\end{tabular}




\begin{tabular}{|l|l|l|l|l|l|l|l|l|l|l|l|l|}
\hline & {$[0.00]$} & {$[0.00]$} & {$[0.00]$} & $* *$ & {$[0.00]$} & {$[1.00]$} & {$[-1.00]$} & $* * *$ & {$[1.00]$} & {$[0.00]$} & {$[-1.00]$} & $* * *$ \\
\hline & $(0.50)$ & $(0.74)$ & & & -0.47 & -0.77 & & & & -0.50 & -0.38 \\
\hline
\end{tabular}

\begin{tabular}{|c|c|c|c|c|c|c|c|c|c|c|c|c|}
\hline \multicolumn{13}{|l|}{ 2: Continued } \\
\hline \multicolumn{5}{|c|}{ Panel A: Full Sample } & \multicolumn{4}{|c|}{ Panel B: Clean Opinion Sample } & \multicolumn{4}{|c|}{ Panel C: Going Concern Sample } \\
\hline & $\begin{array}{l}\text { Non- } \\
\text { Dismissal }(\mathrm{n}= \\
323)\end{array}$ & $\begin{array}{l}\text { Dismissal } \\
(\mathrm{n}=323)\end{array}$ & Difference & & $\begin{array}{l}\begin{array}{l}\text { Non- } \\
\text { Dismissal } \\
(\mathrm{n}=193)\end{array} \\
\end{array}$ & $\begin{array}{l}\text { Dismissal } \\
(\mathrm{n}=193)\end{array}$ & Difference & & $\begin{array}{l}\text { Non- } \\
\text { Dismissal } \\
(\mathrm{n}=130) \\
\end{array}$ & $\begin{array}{l}\text { Dismissal } \\
(\mathrm{n}=130)\end{array}$ & Difference & \\
\hline \multicolumn{13}{|l|}{ CHRGOVEX } \\
\hline & 0.88 & 0.64 & 0.24 & $* * *$ & 1.03 & 0.75 & 0.27 & $* * *$ & 0.66 & 0.48 & 0.18 & \\
\hline & {$[1.00]$} & {$[0.00]$} & {$[1.00]$} & $* * *$ & {$[1.00]$} & {$[0.00]$} & {$[1.00]$} & $* * *$ & {$[0.00]$} & {$[0.00]$} & {$[0.00]$} & $* *$ \\
\hline & $(1.03)$ & $(0.98)$ & & & -1.07 & -0.99 & & & $\begin{array}{c}-0.93 \\
\end{array}$ & -0.94 & & \\
\hline \multicolumn{13}{|l|}{ MEM } \\
\hline & 3.31 & 3.12 & 0.19 & $* * *$ & 3.54 & 3.42 & 0.12 & & 2.98 & 2.68 & 0.30 & $* * *$ \\
\hline & [3.00] & {$[3.00]$} & {$[0.00]$} & $* *$ & {$[3.00]$} & [3.00] & {$[0.00]$} & & {$[3.00]$} & [3.00] & {$[0.00]$} & $* *$ \\
\hline & $(0.91)$ & $(0.96)$ & & & -0.98 & -0.90 & & & $\begin{array}{l}-0.69 \\
\end{array}$ & -0.86 & & \\
\hline \multicolumn{13}{|c|}{ Control Variables } \\
\hline \multicolumn{13}{|l|}{ SIZE } \\
\hline & 1110.10 & 1222.90 & -112.90 & & & & & & & & & \\
\hline & [74.84] & [72.49] & {$[2.35]$} & & & & & & & & & \\
\hline & $(4480.1)$ & $(4759.1)$ & & & & & & & & & & \\
\hline \multicolumn{13}{|l|}{ BLKOWN } \\
\hline & 0.43 & 0.46 & $\begin{array}{l}-0.04 \\
\end{array}$ & & & & & & & & & \\
\hline & {$[0.40]$} & {$[0.39]$} & {$[0.01]$} & & & & & & & & & \\
\hline & $(0.30)$ & $(0.35)$ & & & & & & & & & & \\
\hline \multicolumn{13}{|l|}{ INSOWN } \\
\hline & 0.20 & 0.21 & -0.02 & & & & & & & & & \\
\hline & {$[0.12]$} & {$[0.15]$} & {$[-0.03]$} & & & & & & & & & \\
\hline & $(0.21)$ & $(0.22)$ & & & & & & & & & & \\
\hline \multicolumn{13}{|l|}{ AUDINDS } \\
\hline & 0.28 & 0.03 & 0.00 & & & & & & & & & \\
\hline & {$[0.17]$} & [0.17] & {$[0.00]$} & & & & & & & & & \\
\hline & $(0.23)$ & $(0.23)$ & & & & & & & & & & \\
\hline
\end{tabular}

\begin{tabular}{|c|c|c|c|c|c|c|c|c|c|c|}
\hline \multicolumn{5}{|c|}{ Panel A: Full Sample } & \multicolumn{3}{|c|}{ Panel B: Clean Opinion Sample } & \multicolumn{3}{|c|}{ Panel C: Going Concern Sample } \\
\hline & $\begin{array}{l}\text { Non- } \\
\text { Dismissal } \\
(\mathrm{n}=323)\end{array}$ & $\begin{array}{l}\text { Dismissal } \\
(\mathrm{n}=323)\end{array}$ & Difference $^{d}$ & & $\begin{array}{l}\text { Non- } \\
\text { Dismissal } \\
(\mathrm{n}=193)\end{array}$ & $\begin{array}{l}\text { Dismissal } \\
(\mathrm{n}=193)\end{array}$ & Difference $^{\mathrm{d}}$ & $\begin{array}{l}\text { Non- } \\
\text { Dismissal } \\
(\mathrm{n}=130)\end{array}$ & $\begin{array}{l}\text { Dismissal } \\
(\mathrm{n}=130)\end{array}$ & Difference \\
\hline \multirow[t]{4}{*}{ AUDTEN } & & & & & & & & & & \\
\hline & 6.50 & 8.76 & -2.26 & $* * *$ & & & & & & \\
\hline & {$[5.00]$} & {$[6.00]$} & {$[-1.00]$} & & & & & & & \\
\hline & $(5.21)$ & $(10.10)$ & & & & & & & & \\
\hline \multirow[t]{2}{*}{ CHG } & & & & & & & & & & \\
\hline & 0.37 & 0.45 & -0.09 & $* *$ & & & & & & \\
\hline
\end{tabular}




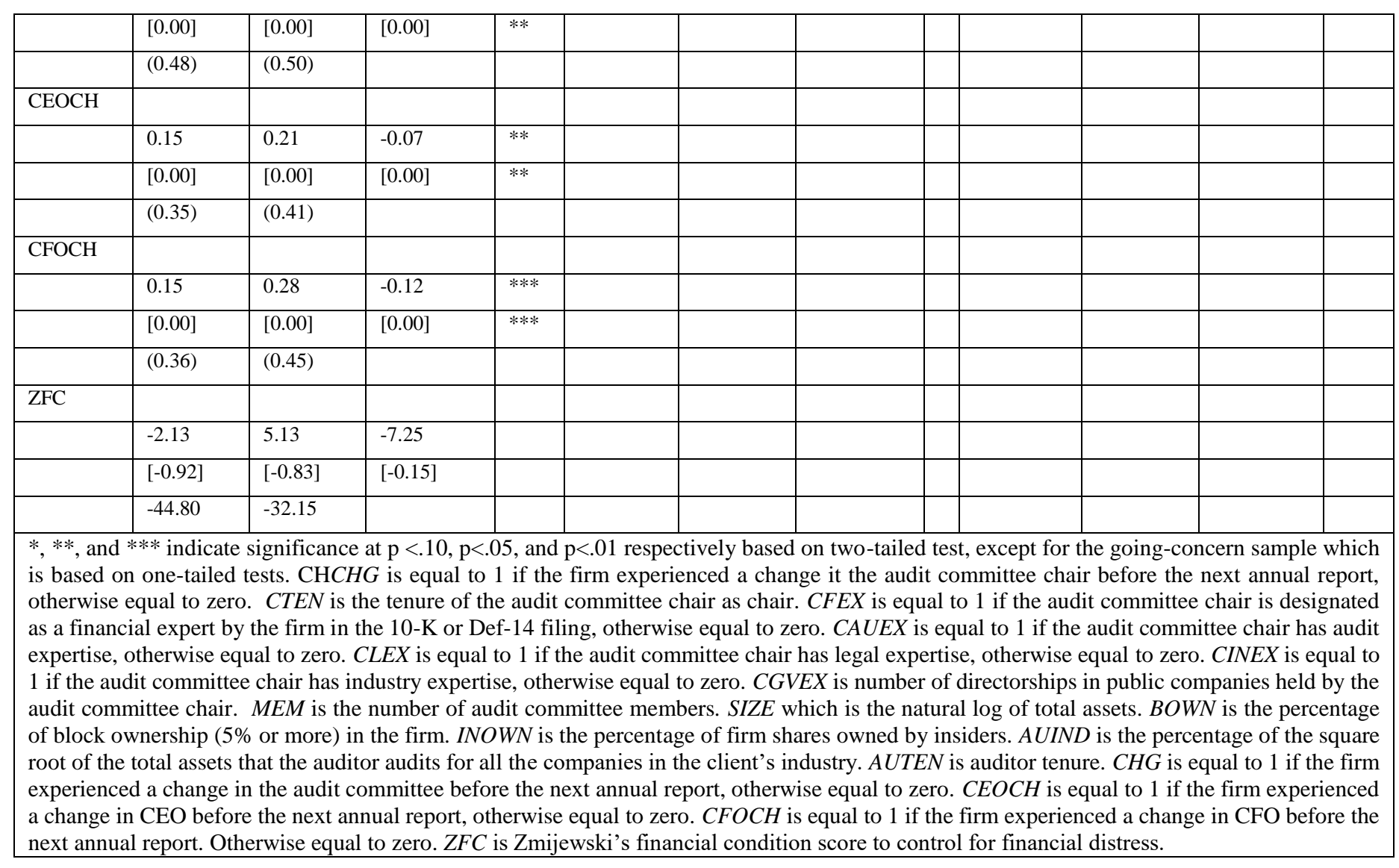

The going concern sample presents the descriptive statistics of paramount interest in this study. The going concern dismissal group is more likely to have a change in audit committee members, $57 \%$ as opposed to $41 \%$ in the non-dismissal group. In general, the non-dismissal group has more audit committee members than does the dismissal group $(2.98$ vs 2.68 , p-value < 0.01$)$. I find $32 \%$ of the going concern dismissal group changes audit committee chair and that these chairs have an average tenure as chair of 3.42; for the non-dismissal group only $18 \%$ (p-value $<0.01$ ) change audit committee chair and these chairs have an average tenure as chair of 4.04 years ( $p$-value $<0.10)$. The dismissal group is significantly less likely to have financial expert chair ( $p$-value $<0.01$ ), audit expert chair ( $p$-value $<0.01$ ), and an industry expert chair ( $\mathrm{p}$-value $<0.01$ ). Furthermore, the audit committee chair for the dismissal group also holds fewer other directorships and is less likely to have legal expertise.

Table 3 presents the correlations among the variables. The correlation coefficients for most of the variables are below 0.40, with the exception of $B O W N$ which has a correlation coefficient of 0.506 with INOWN, however the variance inflation factor is below 2.0 suggesting. Multicollinearity is not a problem. Evidence suggests that firms with larger audit committees (MEM) are more likely to be audited by an industry leader $(\mathrm{rho}=0.259, \mathrm{p}$-value $<0.01)$, to have longer auditor tenure $($ rho $=0.227, \mathrm{p}$-value $<$ 0.01 ) and less likely to experience CEO turnover. They are also more likely to have chairs with governance expertise $(\mathrm{rho}=0.130, \mathrm{p}$-value $<0.01)$, financial expertise (rho $=0.167$, $\mathrm{p}$-value $<0.01$ ), and legal expertise (rho=0.127, p-value $<0.01)$. Audit committee chairs with longer tenures as chair are more likely to have financial expertise (rho $=0.127$, p-value $<0.01)$ and less likely to have audit expertise. Moreover, firms with these audit committee chairs tend to have longer auditor tenures. Audit committee chairs who are financial experts $(C F E X)$ are more likely to be audit experts (rho=0.090, $\mathrm{p}$-value $<0.05)$ and less likely to be legal experts. These chairs are associated with less CFO turnover (rho=-0.128, p- 
value < 0.05), and less CEO turnover. Audit committee chairs that are audit experts are less likely to serve on the committees of financially distressed firms (rho=-0.135, p-value $<0.01$ ). Audit committee chairs with more governance experience are positively associated with audit industry specialist. Audit committee chairs with industry expertise are correlated with longer auditor tenure and CFO turnover.

Unsurprisingly, I find that larger firms in general have less insider ownership, longer auditor tenures, and less financial distress. These firms are more likely to be audited by an industry expert and to have larger audit committees. Also, larger firms tend to have more audit experts, more committee chairs with governance expertise, and more chairs with legal expertise. Finally, I find that firms that experience CFO turnover are more likely to also experience CEO turnover.

Table 3. Pearson correlation coefficients

\begin{tabular}{|c|c|c|c|c|c|c|c|c|c|c|c|c|c|c|c|}
\hline & CHG & BOWN & INOWN & MEM & CFEX & CAUEX & CLEX & CINEX & CTEN & CGVEX & AUTEN & AUIND & ZFC & CFOCH & CEOCH \\
\hline SIZE & 0.031 & -0.071 & \begin{tabular}{|c|}
-0.171 \\
\end{tabular} & 0.256 & 0.009 & 0.046 & 0.087 & 0.014 & -0.045 & 0.080 & 0.175 & 0.246 & $\overline{-}-015$ & -0.071 & 0.013 \\
\hline CHG & & 0.087 & 0.062 & -0.097 & $\begin{array}{l}-0.115 \\
\end{array}$ & $\begin{array}{l}-0.189 \\
\end{array}$ & \begin{tabular}{|l|}
-0.121 \\
\end{tabular} & $\begin{array}{l}-0.108 \\
\end{array}$ & -0.062 & -0.097 & -0.078 & -0.052 & $\begin{array}{l}- \\
0.021\end{array}$ & 0.172 & 0.148 \\
\hline BOWN & & & 0.506 & -0.134 & \begin{tabular}{|l|l|}
-0.136 \\
\end{tabular} & -0.080 & -0.019 & 0.055 & -0.014 & -0.044 & -0.105 & 0.008 & $\begin{array}{l}-015 \\
0.015\end{array}$ & -0.001 & 0.059 \\
\hline INOWN & & & & \begin{tabular}{|c|}
-0.206 \\
\end{tabular} & $\begin{array}{l}-0.131 \\
\end{array}$ & \begin{tabular}{c|c|}
-0.108 \\
\end{tabular} & -0.057 & 0.027 & 0.009 & -0.085 & $\begin{array}{l}-0.103 \\
\end{array}$ & $\begin{array}{l}-0.156 \\
\end{array}$ & 0.031 & 0.008 & 0.007 \\
\hline MEM & & & & & 0.167 & 0.088 & 0.127 & 0.021 & -0.020 & 0.102 & 0.227 & 0.259 & $\begin{array}{l}- \\
0.048\end{array}$ & -0.072 & -0.077 \\
\hline CFEX & & & & & & 0.090 & -0.025 & 0.003 & 0.127 & -0.034 & 0.259 & 0.036 & $\overline{0} .034$ & -0.128 & -0.065 \\
\hline CAUEX & & & & & & & 0.179 & 0.028 & $\begin{array}{l}-0.115 \\
\end{array}$ & 0.113 & 0.097 & 0.106 & $\overline{0.135}$ & -0.096 & -0.070 \\
\hline CLEX & & & & & & & & -0.031 & -0.053 & -0.015 & -0.064 & \begin{tabular}{|c|}
-0.003 \\
\end{tabular} & $\begin{array}{l}- \\
0.027 \\
\end{array}$ & 0.000 & -0.093 \\
\hline CINEX & & & & & & & & & -0.060 & -0.030 & 0.103 & 0.037 & $\begin{array}{l}- \\
0.016 \\
\end{array}$ & 0.080 & 0.006 \\
\hline CTEN & & & & & & & & & & -0.033 & -0.062 & -0.100 & $\begin{array}{l}-010 \\
0.010\end{array}$ & -0.043 & 0.012 \\
\hline CGVEX & & & & & & & & & & & 0.018 & 0.121 & $\begin{array}{l}- \\
0.005\end{array}$ & -0.068 & -0.046 \\
\hline AUTEN & & & & & & & & & & & & 0.307 & $\begin{array}{l}- \\
0.040\end{array}$ & 0.000 & 0.041 \\
\hline AUIND & & & & & & & & & & & & & $\overline{0}-039$ & -0.003 & 0.043 \\
\hline$\overline{\mathrm{ZFC}}$ & & & & & & & & & & & & & & -0.029 & -0.030 \\
\hline $\mathrm{CFOCH}$ & & & & & & & & & & & & & & & 0.330 \\
\hline $\begin{array}{l}\text { Significa } \\
\text { respective }\end{array}$ & at & $\begin{array}{c}.05 \quad \text { an } \\
\text { na }\end{array}$ & $\begin{array}{ll}\mathbf{p}<\quad .01, \\
\end{array}$ & & & & & & & & & & & & \\
\hline
\end{tabular}

\section{Logistic Regression Analysis: Auditor Dismissal and Audit Committee Chair Characteristics}

Table 4 presents the results of the analysis of auditor dismissals and audit committee chair characteristics. As I expected, the likelihood of auditor dismissal after a going concern opinion significantly decreases when the audit committee chair is an audit expert $\left(\beta_{5}+\beta_{6}<0\right.$; $p$-value $\left.<0.01\right)$, when committee chair is a financial expert $\left(\beta_{3}+\beta_{4}<0\right.$; p-value $\left.<0.05\right)$, when committee chair is an industry expert $\left(\beta_{9}+\beta_{10}<0\right.$; p-value $<0.01)$, and when the audit committee chair has more corporate governance experience $\left(\beta_{11}+\beta_{12}\right.$ $<0$; p-value $<0.10)$. I also find a mildly significant positive association between likelihood of auditor dismissal and change in audit committee chair $\left(\beta_{13}+\beta_{14}>0 ; p\right.$-value $\left.<0.10\right)$. I do not find any significant association between auditor dismissal after going concern and the chair's legal expertise. Nor do I find any significant association with audit committee chair tenure.

Similarly, for just the going concern sample, I find a significantly negative association between the likelihood of auditor dismissal and the chair being an audit expert ( $p$-value $<0.01$ ), and chair being an industry expert ( $\mathrm{p}$-value $<0.01)$. I find a significantly negative association ( $\mathrm{p}$-value $<0.05)$ with audit 
chair's governance expertise and financial expertise. The audit committee chair's tenure is negatively associated with dismissal but insignificant. With respect to the clean sample, I again find that the likelihood of auditor dismissal is significantly negatively associated with the audit committee chair's governance expertise ( $\mathrm{p}$-value $<0.05$ ). I find that audit committee chair's audit and industry expertise are positively associated with auditor dismissal while financial expertise and legal expertise are negatively associated. Yet, none of these associations are significant. I find positive significant associations between auditor dismissals and longer auditor tenure (p-value < 0.01); and auditor dismissal and; auditor dismissal and CFO turnover ( $\mathrm{p}$-value $<0.01$ ). On the other hand, I find a significant negative association between dismissal and number of audit committee members ( $p$-value $<0.01)$. Taken in full, the results of examining the association between auditor dismissal and audit committee chair characteristics provide some intriguing new insights.

These findings suggest that audit committee chair's audit expertise and industry expertise provide an incremental benefit beyond general committee members' expertise. Both are significantly negatively associated with auditor dismissals, specifically in the going concern setting. This could be attributed to an audit expert's greater knowledge of the audit process and audit tests enabling him/her to make better informed nuanced decisions as to auditor dismissal and influence the decision of other committee members. The industry expertise may provide the chair with greater knowledge of industry specific risks, accounting, and financial issues. In addition, these results also imply that audit committee chairs with greater corporate governance expertise are important in both a clean opinion report and going concern report setting.

Table 4. Logistic Regression of auditor dismissals on audit committee chair characteristics

\begin{tabular}{|c|c|c|c|c|}
\hline \multicolumn{4}{|c|}{$A U D \_D I S M I S S=\beta_{0}+\beta_{1}{ }^{*} C T E N+\beta_{2}{ }^{*} C T E N{ }^{*} G C+\beta_{3} * C F E X+\beta_{4} * C F E X * G C$} & \\
\hline \multicolumn{5}{|c|}{$+\beta_{5}{ }^{*} C A U E X+\beta_{6} * C A U E X^{*} G C+\beta_{7} * C L E X+\beta_{8} * C L E X * G C$} \\
\hline \multicolumn{5}{|c|}{$+\beta_{9}{ }^{*} C I N E X+\beta_{10} * C I N E X^{*} G C+\beta_{11} * C G V E X+\beta_{12} * C G V E X * G C$} \\
\hline \multicolumn{5}{|c|}{$+\beta_{13} * C C H G+\beta_{14} * C C H G * G C+\beta_{15} * S I Z E+\beta_{16} * I N O W N+\beta_{17} * B O W N$} \\
\hline \multicolumn{5}{|c|}{$+\beta_{18} * A U T E N+\beta_{19} * A U I N D+\beta_{20} * C E O C H+\beta_{21} * C F O C H+\beta_{22} * M E M$} \\
\hline \multicolumn{4}{|c|}{$+\beta_{23} * C H G+\beta_{24} * Z F C+e$} & \\
\hline & Predicted & Est. & Wald Chi- & \\
\hline Variable & Association & Coefficient & $\underline{\text { Square }}$ & \\
\hline Intercept & none & 0.379 & 0.570 & \\
\hline \multicolumn{5}{|c|}{ Audit Committee Chair Characteristics } \\
\hline CTEN & - & -0.036 & 1.073 & \\
\hline $\mathrm{CTEN} * \mathrm{GC}$ & - & 0.040 & 0.481 & \\
\hline Joint test $\left(\beta_{1}+\beta_{2}\right)$ & - & 0.004 & 2.993 & \\
\hline CFEX & none & -0.585 & 1.102 & \\
\hline CFEX*GC & - & -1.019 & 6.310 & ** \\
\hline Joint test $\left(\beta_{3}+\beta_{4}\right)$ & - & -1.604 & 6.517 & ** \\
\hline CAUEX & none & 0.637 & 5.298 & $* *$ \\
\hline CAUEX $* \mathrm{GC}$ & - & -2.368 & 17.971 & $* * *$ \\
\hline Joint test $\left(\beta_{5}+\beta_{6}\right)$ & - & -1.731 & 18.055 & $* * *$ \\
\hline CLEX & none & -0.307 & 1.029 & \\
\hline $\mathrm{CLEX} * \mathrm{GC}$ & - & 1.294 & 2.524 & \\
\hline Joint test $\left(\beta_{7}+\beta_{8}\right)$ & - & 0.987 & 4.118 & \\
\hline CINEX & none & 1.350 & 20.575 & $* * *$ \\
\hline
\end{tabular}




\begin{tabular}{|c|c|c|c|c|}
\hline CINEX*GC & & -3.271 & 29.285 & $* * *$ \\
\hline Joint test $\left(\beta_{9}+\beta_{10}\right)$ & - & -1.921 & 42.058 & $* * *$ \\
\hline CGVEX & none & -0.247 & 4.572 & $* *$ \\
\hline CGVEX*GC & - & 0.176 & 0.864 & \\
\hline Joint test $\left(\beta_{11}+\beta_{12}\right)$ & - & -0.752 & 4.777 & * \\
\hline $\mathrm{CCHG}$ & none & 0.273 & 0.460 & \\
\hline $\mathrm{CCHG}^{*} \mathrm{GC}$ & + & 0.436 & 0.704 & $*$ \\
\hline Joint test $\left(\beta_{13}+\beta_{14}\right)$ & + & 0.709 & 4.432 & * \\
\hline \multicolumn{5}{|l|}{ Control Variables } \\
\hline SIZE & - & -0.043 & 0.961 & \\
\hline INOWN & + & -0.280 & 0.296 & \\
\hline BOWN & - & 0.510 & 2.119 & \\
\hline AUTEN & - & 0.063 & 13.354 & $* * *$ \\
\hline AUIND & - & -0.518 & 1.209 & \\
\hline $\mathrm{CEOCH}$ & + & 0.313 & 1.383 & \\
\hline CFOCH & + & 0.579 & 5.338 & ** \\
\hline MEM & - & -0.250 & 4.745 & $* *$ \\
\hline $\mathrm{CHG}$ & + & 0.130 & 0.391 & \\
\hline ZFC & + & 0.000 & 0.679 & \\
\hline No. of Observations & & 646 & & \\
\hline \multicolumn{2}{|l|}{ Chi-Square of Model } & 126.96 & & \\
\hline (degrees freedom) & & 24 & & \\
\hline p-value & & $<.0001$ & & \\
\hline Pseudo $\mathrm{R}^{2}$ & & 0.261 & & \\
\hline Concordant Pairs & & $79.90 \%$ & & \\
\hline \multicolumn{5}{|c|}{$\begin{array}{l}*, * *, * * * \text { indicate significance at } \mathrm{p}<.10, \mathrm{p}<.05, \mathrm{p}<.01 \text {, respectively. } A U D \_D I S M I S S \text { is equal to one if the firm } \\
\text { dismissed the auditor before the next annual report, otherwise zero. } G C \text { is equal to } 1 \text { if the firm received a going } \\
\text { concern opinion. } C T E N \text { is the tenure of the audit committee chair as chair. } C F E X \text { is equal to } 1 \text { if the audit } \\
\text { committee chair is designated as a financial expert by the firm in the } 10-\mathrm{K} \text { or Def- } 14 \text { filing, otherwise equal to } \\
\text { zero. } C A U E X \text { is equal to } 1 \text { if the audit committee chair has audit expertise, otherwise equal to zero. } C L E X \text { is } \\
\text { equal to } 1 \text { if the audit committee chair has legal expertise, otherwise equal to zero. CINEX is equal to } 1 \text { if the } \\
\text { audit committee chair has industry expertise, otherwise equal to zero. } C G V E X \text { is number of directorships in } \\
\text { public companies held by the audit committee chair. } C C H G \text { is equal to } 1 \text { if the firm experienced a change in } \\
\text { audit committee chair before the next annual report, otherwise equal to zero. SIZE which is the natural log of } \\
\text { total assets. BOWN is the percentage of block ownership (5\% or more) in the firm. INOWN is the percentage of } \\
\text { firm shares owned by insiders. AUIND is the percentage of the square root of the total assets that the auditor } \\
\text { audits for all the companies in the client's industry. AUTEN is auditor tenure. CEOCH is equal to } 1 \text { if the firm } \\
\text { experienced a change in CEO before the next annual report, otherwise equal to } 1 \text {. CFOCH is equal to } 1 \text { if the } \\
\text { firm experienced a change in CFO before the next annual report otherwise equal to } 1 . M E M \text { the number of audit } \\
\text { committee members } C H G \text { is equal to } 1 \text { if the firm experienced a change it the audit committee before the next } \\
\text { annual report, otherwise equal to zero. ZFC is Zmijewski's financial condition score to control for financial } \\
\text { distress. }\end{array}$} \\
\hline
\end{tabular}

\section{Testing Other Explanatory Variables}

The research stream that examines auditor-client relationship proposes that auditor size may affect auditor changes. Healy and Lys (1986) find that larger firms with more complex transactions necessitate more intensive and greater magnitudes of audit work. Thus these firms are more likely to engage a Big 4 auditor better capable of providing those services and are less likely to dismiss the auditor since changing auditors would entail higher switching costs (Hennes et al., 2014). For the full sample in my study, $49 \%$ of the firms were audited by Big 4 auditors in the GC year and 36.5\% in the subsequent year. Although I 
included AUIND variable (auditor's share of clients in an industry) in my model, I did not include a variable to account for Big 4. For my sample, AUIND was highly correlated with whether the auditor was a Big 4 auditor or not. To mitigate any multicollinearity issues, I excluded Big 4 from my model. However, to ensure that this exclusion did not diminish the model fit, manipulate the model, or predictive ability, I re-ran the model once including both variables and once including only the Big 4 variable. In my un-tabulated results, I find that including Big 4 does not alter any of my findings.

Another potential explanatory variable that could influence auditor dismissal is CEO duality. CEO duality occurs when the CEO also serves as the chairman of the board. Agency theory suggests that such a situation could hinder the board's oversight and corporate governance (Fama \& Jensen, 1983). However, the majority of empirical studies have found that CEO duality is largely no better or worse than firms having an independent chairman of the board (Certo, Lester, Dalton, \& Dalton, 2006; Tuggle, Sirmon, Reutzel, \& Bierman, 2010). Nonetheless, separation of the two positions has gained much support in the last 20 years. In 2002, only $25 \%$ of the largest firms in the U.S. separated the two positions; yet in 2014, the percentage increased to $47 \%$ (Spencer Stuart, 2014). Moreover, in a 2009 speech to the Council of Institutional Investors Mary Shapiro, SEC Chair at that time, explicitly stated the SEC's interest in having firms disclose to investors the reason for not separating the two positions (Shapiro, 2009). The above suggests that CEO duality could play a role in auditor dismissals in the going concern context. Thus, I re-test the logit model with a dummy variable controlling for CEO duality. Table 5 provides the results of re-running the model with the dummy variable for CEO duality. My original finding holds and in addition, I find that the likelihood of auditor dismissal after a going concern opinion is significantly positively associated CEO duality $(C E O C H R)$ at p-value $<0.01$.

Table 5. Logistic Regression of auditor dismissals on audit committee chair characteristics with entrenched CEO

\begin{tabular}{|c|c|c|c|c|}
\hline \multicolumn{4}{|c|}{$A U D \_D I S M I S S=\beta_{0}+\beta_{1} * C T E N+\beta_{2} * C T E N^{*} G C+\beta_{3} * C F E X+\beta_{4} * C F E X * G C$} & \\
\hline \multicolumn{5}{|c|}{$+\beta_{5}{ }^{*} C A U E X+\beta_{6}{ }^{*} C A U E X^{*} G C+\beta_{7} * C L E X+\beta_{8} * C L E X^{*} G C$} \\
\hline \multicolumn{5}{|c|}{$+\beta_{9} *$ CINEX $+\beta_{10} * C I N E X^{*} G C+\beta_{11} * C G V E X+\beta_{12} * C G V E X * G C$} \\
\hline \multicolumn{5}{|c|}{$+\beta_{13} * C C H G+\beta_{14} * C C H G * G C+\beta_{15} * C E O C H R+\beta_{16} * C E O C H R * G C$} \\
\hline \multicolumn{5}{|c|}{+ Control Variables $+e$} \\
\hline & Predicted & Est. & Wald Chi- & \\
\hline Variable & Association & Coefficient & Square & \\
\hline Intercept & none & 0.006 & 0.03 & \\
\hline \multicolumn{5}{|c|}{ Audit Committee Chair Characteristics } \\
\hline CTEN & $\square$ & -0.054 & 2.497 & \\
\hline CTEN*GC & $\square$ & 0.05 & 0.79 & \\
\hline Joint test $\left(\beta_{1}+\beta_{2}\right)$ & $\square$ & -0.004 & 2.993 & \\
\hline CFEX & none & -0.44 & 1.102 & \\
\hline CFEX*GC & $\square$ & 0.829 & 6.31 & * \\
\hline Joint test $\left(\beta_{3}+\beta_{4}\right)$ & $\square$ & 0.389 & 6.517 & \\
\hline CAUEX & none & 0.662 & 5.693 & $* * *$ \\
\hline CAUEX $* \mathrm{GC}$ & $\square$ & -2.437 & 18.568 & $* * *$ \\
\hline Joint test $\left(\beta_{5}+\beta_{6}\right)$ & $\square$ & -1.775 & 18.055 & $* * *$ \\
\hline CLEX & none & 0.131 & 1.029 & \\
\hline CLEX*GC & $\square$ & 1.111 & 2.524 & \\
\hline Joint test $\left(\beta_{7}+\beta_{8}\right)$ & $\square$ & 1.242 & 4.118 & \\
\hline CINEX & none & 1.383 & 26.233 & *** \\
\hline CINEX*GC & & -3.415 & 47.09 & $* * *$ \\
\hline
\end{tabular}




\begin{tabular}{|c|c|c|c|c|}
\hline Joint test $\left(\beta_{9}+\beta_{10}\right)$ & $\square$ & -2.032 & 42.058 & $* * *$ \\
\hline CGVEX & none & -0.24 & 4.572 & $* *$ \\
\hline CGEX*GC & $\square$ & 0.198 & 0.864 & \\
\hline Joint test $\left(\beta_{11}+\beta_{12}\right)$ & $\square$ & -0.752 & 4.777 & $*$ \\
\hline $\mathrm{CCHG}$ & none & 0.269 & 0.46 & \\
\hline $\mathrm{CCHG}^{*} \mathrm{GC}$ & + & 0.24 & 0.704 & \\
\hline Joint test $\left(\beta_{13}+\beta_{14}\right)$ & + & 0.509 & 2.082 & \\
\hline CEOCHR & none & 0.145 & 0.387 & \\
\hline CEOCHR $* \mathrm{GC}$ & + & 0.738 & 3.92 & $* *$ \\
\hline Joint test $\left(\beta_{15}+\beta_{16}\right)$ & + & 0.884 & 8.539 & $* * *$ \\
\hline \multicolumn{5}{|l|}{ Control Variables } \\
\hline SIZE & $\square$ & -0.041 & 0.721 & \\
\hline INSOWN & + & -0.363 & 0.486 & \\
\hline BLKOWN & $\square$ & 0.512 & 2.085 & \\
\hline AUDTEN & $\square$ & 0.065 & 13.036 & *** \\
\hline AUDINDS & $\square$ & -0.499 & 1.093 & \\
\hline $\mathrm{CEOCH}$ & + & 0.3302 & 1.507 & \\
\hline $\mathrm{CFOCH}$ & + & 0.562 & 4.915 & $* *$ \\
\hline MEM & $\square$ & -0.234 & 4.058 & $* *$ \\
\hline $\mathrm{CHG}$ & + & 0.121 & 0.334 & \\
\hline ZFC & + & 0 & 0.679 & \\
\hline No. of Observations & & 646 & & \\
\hline Chi-Square of Model & & 126.96 & & \\
\hline (degrees freedom) & & 24 & & \\
\hline p-value & & $<.0001$ & & \\
\hline Pseudo $\mathrm{R}^{2}$ & & 0.261 & & \\
\hline Concordant Pairs & & $79.90 \%$ & & \\
\hline \multicolumn{5}{|c|}{ 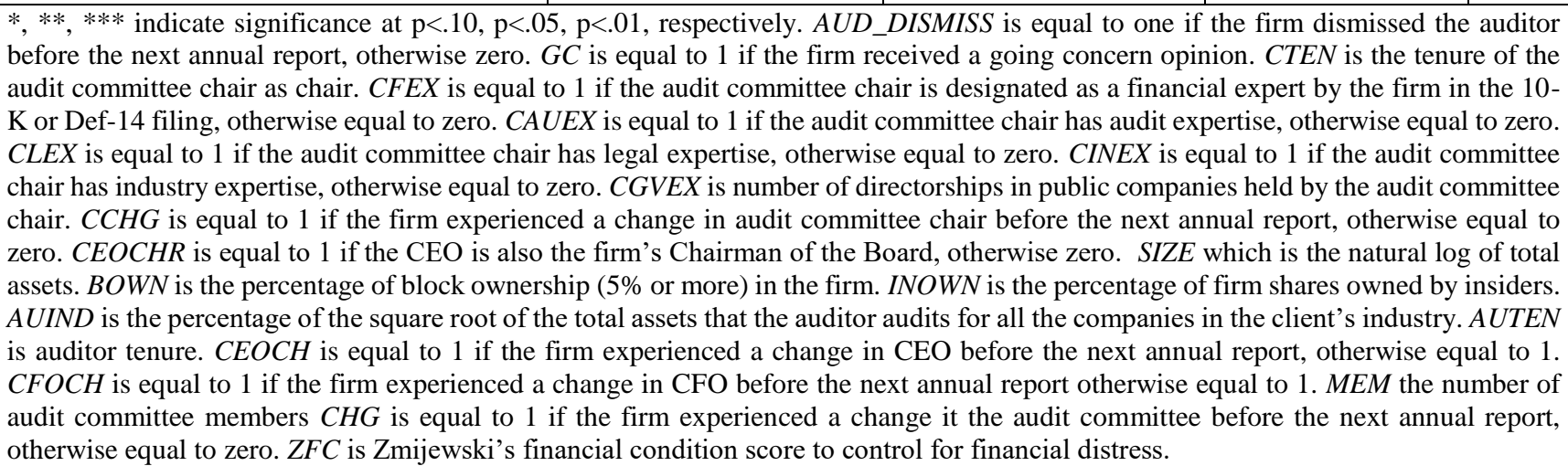 } \\
\hline
\end{tabular}

\section{Audit Committee Chair Expertise in Subsequent Year}

Based on the evidence, the turnover rate of audit chairs is higher for the dismissal group and within the dismissal group, it is higher for the going concern opinion group. It is impossible to predict whether the new audit chairs will have financial, audit, and/or legal expertise and if this will differ between groups. Yet I believe the incremental contribution of this paper is based in the audit committee chair findings; therefore, some preliminary findings as to the subsequent year can provide some evidence as to the overall effectiveness of corporate governance and to encourage further research. To that end, I also examined the proportions of audit committee chair expertise categories for the clean and going concern samples in the year after the original opinion for all firms that experienced audit chair turnover. Table 6 Panel A provides 
the percentage of audit committee chairs that are financial experts, audit experts, legal expert and industry experts for the clean opinion sample that changed audit committee chairs. The differences for each category of expertise are not significant between the dismissal and non-dismissal group with the exception of legal expertise ( $p$-value $<0.05$ ). It seems that non-dismissal firms have a greater percentage of audit committee chairs with legal expertise in the subsequent year.

Table 6 Panel B provides the percentages for the four expertise categories for the going concern opinion. I find a significant difference between the dismissal and non-dismissal group for audit expertise (p-value $<0.01$ ), industry expertise (p-value $<0.05$ ) and legal expertise. I find that $38.1 \%$ of the nondismissal groups' new audit chairs have audit expertise whereas only $12.2 \%$ of the dismissal group chairs have audit expertise. About $2.4 \%$ of the dismissal group chairs have legal expertise compared to $13 \%$ of the non-dismissal group chairs. Nearly $52 \%$ of the non-dismissal group have industry expert audit chairs compared to $26.8 \%$ for the dismissal group. It is important to note that the sample size is quite small thus limits the inferences that can be made. But these finding suggests that within the going concern sample of firms that experienced audit committee chair turnover, the non-dismissal group tends to appoint new chairs with greater expertise. However, these findings need to be explored in greater context with other factors that influence audit committee appointments before drawing any sound conclusions.

Table 6. Percentage of audit committee chairs with financial expertise, audit expertise, legal expertise, and industry expertise on the audit committee in the following year for firms that experienced audit chair turnover

\begin{tabular}{|l|l|l|l|l|}
\hline Panel A: Clean Opinion Sample (n=40) & $\begin{array}{l}\text { Non- } \\
\text { Dismissal }\end{array}$ & Dismissed $^{(\mathrm{b})}$ & & \\
\hline & Auditor & Auditor & Difference & P-value $^{(\mathrm{c})}$ \\
\hline Audit Committee Chair is Financial Expert $(\mathrm{n}=37)$ & $94 \%$ & $91 \%$ & $4 \%$ & 0.726 \\
\hline Audit Committee Chair is Audit Expert (n=8) & $33 \%$ & $41 \%$ & $-8 \%$ & 0.608 \\
\hline Audit Committee Chair is Legal Expert (n=6) & $27.78 \%$ & $4.55 \%$ & $23 \%$ & 0.043 \\
\hline Audit Committee Chair is Industry Expert (n=28) & $44.40 \%$ & $45.50 \%$ & $-1 \%$ & 0.945 \\
\hline Panel B: Going Concern Sample $(n=64)$ & $\begin{array}{l}\text { Non- } \\
\text { Dismissal }\end{array}$ & Dismissed & \\
\hline & Auditor & Auditor & Difference & P-value \\
\hline Audit Committee Chair is Financial Expert (n= 55) & $87.00 \%$ & $85.40 \%$ & $1.59 \%$ & 0.864 \\
\hline Audit Committee Chair is Audit Expert (n=20) & $38.10 \%$ & $12.20 \%$ & $25.90 \%$ & 0.001 \\
\hline Audit Committee Chair is Legal Expert (n=4) & $13.00 \%$ & $2.40 \%$ & $10.60 \%$ & 0.095 \\
\hline Audit Committee Chair is Industry Expert (n=23) & $52.20 \%$ & $26.80 \%$ & $25.34 \%$ & 0.044 \\
\hline $\begin{array}{l}\text { (a) } 18 \text { firms in this group changed AC Chair, (b) 22 firms in this group changed AC chair, (c) Based on Z-statistic for difference in proportions } \\
\text { across the two groups, (d) 23 firms in this group changed AC Chair, (e) 41 firms in this group changed AC Chair }\end{array}$ & \\
\hline
\end{tabular}

\section{CONCLUSION AND LIMITATIONS}

A deep research stream in both the pre-SOX and post-SOX periods studies audit committee composition and effective corporate governance. In general, these studies focus on providing insights as to the role independence and expertise play in establishing audit committee effectiveness. Much of the expertise papers naturally focus on financial expertise yet investors, regulators, and audit committee associations have all expressed a need for greater understanding of other types of expertise. Moreover, in effort to continue to improve the effectiveness and quality of audit committees, regulators and shareholders have shown interest in further enhancing audit committee chair responsibilities and member criteria. This paper 
contributes to the existing literature and provides regulators with useful information as to future audit committee improvements. I find new evidence that suggests firms with a greater percentage of audit experts and industry experts on the audit committee are less likely to dismiss the auditor after a going concern opinion thus suggesting these types of expertise may enhance the committee monitoring and corporate governance role in financially weak companies. My findings suggest that larger audit committees and committees with greater governance experience are less likely to dismiss the auditor after a going concern opinion; implying that perhaps such audit committees are more effective in their governance role. Moreover, the main contribution of this paper is found in the audit committee chair evidence. I find that the financial expertise, audit expertise, and industry expertise of the chair provides incremental benefits suggesting these types of expertise may enhance the committee monitoring and corporate governance role in financially weak companies. These results extend the audit committee literature by providing initial evidence suggesting that specifically, audit committee chair expertise, may strengthen the committee's monitoring role. These findings are relevant especially as investor interest in the backgrounds and experience of audit committee chairs has increased. These results suggest that establishing criteria specific to the audit committee chair can be another conduit towards improving corporate governance and audit quality. These results also provide empirical support for the ACLN's interest in developing and strengthening the audit committee and the audit committee chair's role via greater and different expertise.

This study is not without obvious limitations. First, firms dismiss an auditor for a variety of reasons; and while my study provides some evidence of an association between auditor dismissals and audit committee chair characteristics, I make no presumptions as to causation. Furthermore, although I employ a model used in previous research, this does not preclude the possible omission of variables that are correlated with my dependent and independent variables. Moreover, my study is based on descriptive characteristics of the audit committee chair but it may be that some other unobservable dynamic of the audit committee drives the association. Further research could examine the role of other forms of expertise such as risk assessment expertise, information system expertise, and cyber security expertise in audit committee effectiveness. Another interesting research avenue could explore audit committee chair compensation and auditor dismissals after going concern opinions.

\section{REFERNCES}

Abernathy, J. L., Beyer, B., Masli, A., \& Stefaniak, C. (2014). The association between characteristics of audit committee accounting experts, audit committee chairs, and financial reporting timeliness. Advances in Accounting, 30(2), 283-297.

Abbott, L. J., Parker, S., Peters, G. F., \& Raghunandan, K. (2003). The association between audit committee characteristics and audit fees. Auditing: A Journal of Practice \& Theory, 22(2), 17-32.

Al-Absy, M. S. M., Ismail, K. N. I. K., \& Chandren, S. (2019). Audit committee chairman characteristics and earnings management. Asia-Pacific Journal of Business Administration.

Alhababsah, S., \& Yekini, S. (2021). Audit committee and audit quality: An empirical analysis considering industry expertise, legal expertise and gender diversity. Journal of International Accounting, Auditing and Taxation, 42, 100377. 
Archambeault, D., \& De Zoort, F. T. (2001). Auditor opinion shopping and the audit committee: An analysis of suspicious auditor switches. International Journal of Auditing, 5(1), 33-52.

Audit Committee Leadership Network. (2012). Enhancing the audit committee report: A call action.

Retrieved

https://www.tapestrynetworks.com/sites/default/files/publication_pdf/Enhancing\%20the

from \%20audit\%20committee\%20report\%20-\%20A\%20call\%20to\%20action.pdf

Audit Committee Leadership Network. (2014). Improving audit committee performance.Retrieved from https://www.tapestrynetworks.com/publications/improving-audit-committee-performance $\% 2016 \% 20$ October\%202014\%20-\%20Final\%20WEB.pdf

Audit Committee Leadership Network. (2019). Oversight of corporate culture. Retrieved from https://www.tapestrynetworks.com/publications/oversight-corporate-culture-0

Beasley, M. S., Carcello, J. V., Hermanson, D. R., \& Neal, T. L. (2009). The audit committee oversight process. Contemporary Accounting Research, 26(1), 65-122.

Bédard, J., \& Gendron, Y. (2010). Strengthening the financial reporting system: can audit committees deliver? International Journal of Auditing, 14(2), 174-210.

Carcello, J. V., \& Neal, T. L. (2000). Audit committee composition and auditor reporting. The Accounting Review, 75(4), 453-467.

Carcello, J. V., \& Neal, T. L. (2003). Audit committee characteristics and auditor dismissals following "new” going-concern reports. The Accounting Review, 78(1), 95-117.

Carcello, J. V., Hermanson, D. R., Neal, T. L., \& Riley, R. A. (2002). Board characteristics and audit fees. Contemporary Accounting Research, 19(3), 365-384.

Carcello, J. V., Hermanson, D. R., \& Ye, Z. (2011). Corporate governance research in accounting and auditing: Insights, practice implications, and future research directions. Auditing: $A$ Journal of Practice \& Theory, 30(3), 1-31.

Center for Audit Quality. (2013). Enhancing the audit committee report: A call to action. Retrieved from https://www.thecaq.org/enhancing-audit-committee-report-call-action/

Certo, S. T., Lester, R. H., Dalton, C. M., \& Dalton, D. R. (2006). Top management teams, strategy and financial performance: A meta-analytic examination. Journal of Management Studies, 43(4), 813-839.

Chan, K. H., Lin, K. Z., \& Mo, P. L. L. (2006). A political-economic analysis of auditor reporting and auditor switches. Review of Accounting Studies, 11(1), 21-48. 
Chaudhry, N. I., Roomi, M. A., \& Aftab, I. (2020). Impact of expertise of audit committee chair and nomination committee chair on financial performance of firm. Corporate Governance: The International Journal of Business in Society.

Cohen, J., Krishnamoorthy, G., \& Wright, A. M. (2002). Corporate governance and the audit process. Contemporary Accounting Research, 19(4), 573-594.

Cohen, J., Hoitash, U., Krishnamoorthy, G., \& Wright, A. (2014). The effect of audit committee industry expertise on monitoring the financial reporting process. The Accounting Review, 89(1), 243-273.

Contessotto, C., \& Moroney, R. (2014). The association between audit committee effectiveness and audit risk. Accounting \& Finance, 54(2), 393-418.

DeFond, M. L., Hann, R. N., \& Hu, X. (2005). Does the market value financial expertise on audit committees of boards of directors? Journal of Accounting Research, 43(2), 153-193.

DeZoort, F. T. (1998). An analysis of experience effects on audit committee members' oversight judgments. Accounting, Organizations and Society, 23(1), 1-21.

DeZoort, F. T., Hermanson, D. R., Archambeault, D. S., \& Reed, S. A. (2002). Audit committee effectiveness: A synthesis of the empirical audit committee literature. Audit Committee Effectiveness: A Synthesis of the Empirical Audit Committee Literature, 21, 38.

Dye, R. A. (1991). Informationally motivated auditor replacement. Journal of Accounting and Economics, 14(4), 347-374.

Fama, E. F., \& Jensen, M. C. (1983). Separation of ownership and control. Journal of Law and Economics, 301-325.

Ghafran, C., \& Yasmin, S. (2018). Audit committee chair and financial reporting timeliness: A focus on financial, experiential, and monitoring expertise. International Journal of Auditing, 22(1), 13-24.

Haerem, T., \& Rau, D. (2007). The influence of degree of expertise and objective task complexity on perceived task complexity and performance. Journal of Applied Psychology, 92(5), 1320.

Healy, P., \& Lys, T. (1986). Auditor changes following Big Eight mergers with non-Big Eight audit firms. Journal of Accounting and Public Policy, 5(4), 251-265.

Hennes, K. M., Leone, A. J., \& Miller, B. P. (2014). Determinants and market consequences of auditor dismissals after accounting restatements. The Accounting Review, 89(3), 10511082.

Landsman, W. R., Nelson, K. K., \& Rountree, B. R. (2009). Auditor switches in the pre-and post-Enron eras: risk or realignment? The Accounting Review, 84(2), 531-558. 
Lee, T \& Stone, M. (2003). Economic agency and audit committees: responsibilities and membership composition. International Journal of Auditing, 1(2), 97-116, 2003.

Lee, H. Y., Mande, V., \& Ortman, R. (2004). The effect of audit committee and board of director independence on auditor resignation. Auditing: A Journal of Practice \& Theory, 23(2), $131-146$

Martinov-Bennie, N., Soh, D., \& Tweedie, D. (2015). An investigation into the roles, characteristics, expectations, and evaluation practices of audit committees. Managerial Auditing Journal, 30(8/9), 727-755.

Menon, K., \& Williams, D. D. (2008). Management turnover following auditor resignations. Contemporary Accounting Research, 25(2), 567-604.

Naiker, V., Sharma, D. S., \& Sharma, V. D. (2013). Do former audit firm partners on audit committees procure greater nonaudit services from the auditor? The Accounting Review, 88(1), 297-326.

NYSE Listed Company Manual. (2021). Section 3.Retrieved from http://nysemanual.nyse.com/LCM/Sections/

PCAOB Investor Advisory Group (IAG). (2012). The Sarbanes-Oxley Act ten years later: auditor independence, objectivity, and skepticism. IAG Working Group Presentation. Retrieved from https://pcaobus.org/News/Events/Documents/03282012_IAGMeeting/Independence_Obj ectivity_Working_Group_Report.pdf

PCAOB. (2020). Conversations with audit committee chairs: What we heard and FAQ. Retrieved from https://pcaobus.org/Documents/Conversations-with-Audit-Committee-Chairs.pdf

PricewaterhouseCoopers L. L. P. (2003). Audit committees: good practices for meeting market expectations. 2nd Ed. Retrieved from http://www.pwc.com/gx/en/ifrsreporting/corporategovernance-publications audit-committees.jhtm

Public Oversight Board. (1993). A special report by the Public Oversight Board of the SEC Practice section, AICPA. Retrieved from https://egrove.olemiss.edu/cgi/viewcontent.cgi?article=1209\&context=aicpa_assoc

Salleh, Z., \& Stewart, J. (2013). Audit committee involvement in resolving contentious accounting issues: perceptions of chief financial officers, audit committee chairs and external auditors in Malaysia. International Journal of Accounting, Auditing and Performance Evaluation, 9(4), 326-343.

Sarbanes-Oxley Act (SOX). (2002). Public Law No. 107-204, 116 Stat. 745 Sec1-1107.

Securities and Exchange Commission (SEC). (2003). Final Rule: Standards relating to listed company audit committees. Release 33-8220. 
Schmidt, J., \& Wilkins, M. S. (2013). Bringing darkness to light: The influence of auditor quality and audit committee expertise on the timeliness of financial statement restatement disclosures. Auditing: A Journal of Practice \& Theory, 32(1), 221-244.

Schwartz, K. B., \& Menon, K. (1985). Auditor switches by failing firms. The Accounting Review, 248261.

Shapiro, M.L.(Director)(2009, April 6). Address to the Council of Institutional Investors. Council of Institutional Investors Spring 2009 Meeting, Washington D.C. Retrieved from https://www.sec.gov/news/speech/2009/spch040609mls.htm

Spencer Stuart. (2014). Spencer Stuart Board Index. Retrieved from https://www.nyse.com/publicdocs/nyse/listing/Spencer_Stuart_Board_Index_2014.pdf.

Tanyi, P. \& Smith, D. (2015). Busyness, expertise, and financial reporting quality of audit committee chairs and financial experts. Auditing: A Journal of Practice \& Theory, 34(2), 59-89.

Teoh, S. H. (1992). Auditor independence, dismissal threats, and the market reaction to auditor switches. Journal of Accounting Research, 1-23.

Tuggle, C. S., Sirmon, D. G., Reutzel, C. R., \& Bierman, L. (2010). Commanding board of director attention: investigating how organizational performance and CEO duality affect board members' attention to monitoring. Strategic Management Journal, 31(9), 946-968.

Weiss, D. J., \& Shanteau, J. (2014). Who's the best? A relativistic view of expertise. Applied Cognitive Psychology, 28(4), 447-457.

Zmijewski, H. (1984). Methodological issues related to the estimation of financial distress prediction model. Journal of Accounting Research, 59-82.

\section{Copyrights}

Copyright for this article is retained by the author(s), with first publication rights granted to the journal. This is an open-access article distributed under the terms and conditions of the Creative Commons Attribution license (http://creativecommons.org/licenses/by/4.0/). 